autoconciencia después de la decepción en las relaciones que Mila intenta construir en las solitarias tierras montañesas. La ocultación y la soledad como precio a pagar, sin embargo, sostiene Carbonell, se abren paso en la representación de estas mujeres indómitas con la potencia afirmativa de una jouissance d'être que desafía los significantes impuestos a la mujer. Finalmente, dos capítulos analizan los personajes femeninos de La Regenta (1885): Jo Labany formula la hipótesis de que la teoría de los afectos, con especial atención a los afectos negativos que provocan estancamiento de la agencia, podría dar las claves para comprender dimensiones no exploradas de esta obra y del carácter de su protagonista; su repliegue en la pasividad sería lo que mueve la acción. Finalmente, Smith parte del ensayo Female Masculitity (1998) de Jack Halberstam para analizar la hibridación de los sexos que se mostraría en la novela como un fenómeno que rompe con las jerarquías de los géneros y serviría para denunciar la decadencia de los valores tradicionales.

Nos encontramos, sin duda, con una brillante revisión de figuras centrales del siglo XIX que abre nuevas vías de lectura e interpretación.

D.O.I.: 10.1344/Lectora2021.27.19

María Xesús Lama LóPEZ lama@ub.edu

Universitat de Barcelona

\title{
Hannah Arendt: libertad política y totalitarismo
}

Fina Birulés

Barcelona, Gedisa, 2019, 127 pp. ISBN: 978-84-18193-67-5

Con el correr de los años han ido avanzando los estudios sobre la obra de Hannah Arendt y la edición o reedición de sus libros y ensayos en distintos idiomas. Su recepción en España y en los países latinoamericanos se ha enriquecido gracias a las traducciones e investigaciones que ha realizado la filósofa catalana Fina Birulés con gran sensibilidad, inteligencia y rigor. En este libro, la autora opta por presentar algunos temas y observaciones entremezclados con la biografía de la pensadora política judeoalemana antes de detenerse en un estudio detallado sobre el totalitarismo. En la primera parte ("En las entretelas de vida y pensamiento"), toma como punto de partida de su indagación la experiencia de Arendt del exilio; un viaje incierto que comienza con un paso y que arroja a los refugiados a vivir en suelo extranjero, donde se puede perder la espontaneidad de la lengua materna por una segunda lengua y, con ello, la naturalidad de los gestos y la expresión de los sentimientos. Pese a ello, Arendt encuentra las palabras para poder comprender este fenómeno con sus límites y alcances propios.

En la segunda parte ("El totalitarismo, un fenómeno sin precedentes"), Birulés señala cómo la gramática del mal ha implicado casi siempre la idea de intención 
maligna; no obstante, los crímenes atroces cometidos por el totalitarismo nazi no estaban necesariamente ligados a "motivos abominables". La novedad de esta maldad extrema no se halla en el número de víctimas, sino en el absurdo ideológico que provocó esta tragedia: en la mecanización de su ejecución y la institución de un mundo donde las víctimas eran privadas de su humanidad. Birulés analiza algunas raíces que desembocaron en la aparición del fenómeno totalitario, especialmente el antisemitismo moderno que surgió después de la emancipación de las poblaciones judías en Europa en el siglo XIX y el imperialismo que se desprendió de la colonización europea. Aunque Arendt no comparta la tesis de la victimización absoluta según la cual el genocidio fue causado por el eterno antisemitismo, comprende que el pueblo judío se había caracterizado por su acosmismo y su "carácter apolítico". Con el totalitarismo, vemos como el antisemitismo nazi conduce a un exterminio racionalmente perpetrado por todos los aparatos del Estado y legitimado por amplios sectores de la población alemana. La autora aborda otro elemento importante que cristalizará en el fenómeno totalitario: el imperialismo europeo que puso en jaque los cimientos de los Estados nación. La pensadora judeoalemana encuentra esta variante en el pangermanismo y el paneslavismo, los cuales suponían una consciencia tribal capaz de unir a los pueblos de un origen similar para dominar el resto del mundo.

Una de las principales características de los regímenes totalitarios es que rompen con las distinciones tradicionales entre gobierno legal e ilegal, entre poder legítimo y poder arbitrario. Mientras que una tiranía es un gobierno ilegal donde el poder es ejercido de forma arbitraria e ilegítima, en el caso de los totalitarismos, los gobernantes se consideran a sí mismos servidores de unas leyes sobrehumanas que rigen el universo, ya sean las leyes de la Naturaleza o la Historia. Más allá de toda ilegalidad, buscan legitimar todas sus acciones a partir de estas leyes como fuentes últimas de autoridad en aras de producir una nueva humanidad. Para lograr este propósito, los gobernantes totalitarios necesitan manipular el comportamiento de los ciudadanos a través de la ideología para imposibilitar su capacidad para comprender, y así destruir la capacidad de tener una opinión o juicio propio. Según Arendt, la ideología es la lógica de una idea y su característica esencial es la consistencia lógica con la que pretende explicar científicamente las acciones humanas. El pensamiento ideológico se vuelve independiente de cualquier realidad y se emancipa de cualquier experiencia, destruyendo el sentido común a través del terror. El movimiento totalitario no se detiene en la eliminación de los opositores políticos, sino que sigue desplegándose y es así como el terror se hace total.

En la tercera parte (“Aislamiento y soledad”), Birulés expone cómo los totalitarismos no buscan gobernar despóticamente a los seres humanos, sino consolidar una megaestructura donde éstos sean superfluos a través de la destrucción de la espontaneidad humana. Por ende, los campos de concentración y exterminio son 
las instituciones más consecuentes de los regímenes totalitarios, en la medida en que en ellos se puede lograr su ideal social de dominación total. Si la ideología nazi establecía como principio el antisemitismo y la destrucción de las comunidades judías, es en los campos donde los internados pueden ser arrojados del mundo como acción lógica deducida de sus premisas. Al comprimir a los internos unos contra otros como un anillo de hierro que los uniformiza e igualaba, Birulés plantea que la dominación totalitaria no solo busca el aislamiento (isolation) cuando destruye la esfera política, donde todos actúan en pos de un interés común, sino también eliminar la dimensión privada al condenar a los hombres a la soledad (loneliness) que representa la experiencia desesperada de no pertenecer al mundo. De este modo, la dominación totalitaria no solo implica la conversión de los seres humanos en seres superfluos, sino también la pérdida del mundo compartido.

En este libro, sin duda alguna, Fina Birulés guía a los lectores, con las palabras iluminadoras que siempre la han caracterizado, a dirigir su atención hacia las reflexiones arendtianas sobre el totalitarismo sin olvidar que debemos pensar en campo abierto y no ser ciegos a los males de nuestro tiempo.

YULIANA LEAL GRANOBLES yuliana.leg@gmail.com

D.O.I.: 10.1344/Lectora2021.27.20

Pontificia Universidad Católica de Chile

\section{The Force of Non-Violence: An Ethico-Political Bind ${ }^{1}$}

Judith Butler

Nueva York, Verso, 2020, 209 pp. ISBN: 978-1-78873-276-5

Esta monografía de Judith Butler se propone repensar el significado de la no violencia en el marco ético que ha ido construyendo en los últimos años: el de la interdependencia. Se trata de un tema que ya presentó en el último capítulo de Marcos de Guerra. Las vidas lloradas (Paidós, 2017), titulado "La pretensión de la no violencia”. Butler aporta una nueva mirada sobre la cuestión de qué vidas merecen ser vividas; idea siempre relevante y más aún en el contexto de la pandemia actual, donde se ha hecho patente que hay vidas que se valoran más que otras. Con este ensayo, la autora apuesta por clarificar cómo se han construido las diferentes nociones de violencia dentro de cada contexto y nos propone un marco de pensamiento para evitar caer en un relativismo general y desesperanzador.

\footnotetext{
${ }^{1}$ Traducido recientemente al catalán y al castellano: La força de la no-violència. Un vincle èticopolític, traducción de Lourdes Bigorra (Manresa, Tigre de Paper, 2021) y La fuerza de la no violencia. La ética en lo político, traducción de Marcos Mayer (Barcelona, Paidós, 2021).
} 